\title{
Folate Hydrolase mRNA Measurement
}

National Cancer Institute

\section{Source}

National Cancer Institute. Folate Hydrolase mRNA Measurement. NCI Thesaurus. Code C132367.

The determination of the amount of folate hydrolase mRNA in a biological sample. 